\title{
Perawatan Kuretase Gingiva pada Gigi Premolar Kiri Rahang Atas: Laporan Kasus
}

\author{
Johanna A. Khoman, Gabriella A. Singal
}

\author{
Program Studi Pendidikan Dokter Gigi Fakultas Kedokteran Universitas Sam Ratulangi \\ Manado \\ Email: gbypenting@gmail.com
}

\begin{abstract}
Periodontal disease has still a high prevalence in the community. It occurs due to the accumulation of plaque or calculus on the tooth surface. The plaque, a thin layer of biofilm, contains a collection of pathogenic microorganisms that cause periodontal tissue and bone disease. The initial treatment of periodontal disease is to eliminate the etiological factors, namely scaling, root planning, and curettage. Curettage is a mechanical cleaning action in periodontitis therapy to remove inflammatory tissue, calculus, and bacterial colonies. This study was aimed to discuss the management of gingival curettage treatment in a 26-year-old female patient who had gingivitis with a $4 \mathrm{~mm}$ deep periodontal pocket in her maxillar left premolar, treated with scaling and gingival curettage. Clinical further examination after treatment revealed that the gingiva looked normal without any swelling, and the pocket depth had decreased by about $2 \mathrm{~mm}$.
\end{abstract}

Keywords: periodontal disease, periodontal pocket, gingival curettage

\begin{abstract}
Abstrak: Prevalensi penyakit periodontal masih cukup tinggi di masyarakat. Penyakit periodontal diawali ketika plak atau kalkulus terakumulasi pada permukaan gigi. Plak merupakan lapisan tipis biofilm berisi kumpulan mikroorganisme patogen yang menyebabkan kerusakan jaringan periodontal dan tulang. Perawatan awal pada penyakit periodontal ialah dengan menghilangkan faktor etiologi yaitu dengan scalling, root planning, dan kuretase. Kuretase merupakan tindakan pembersihan secara mekanis dalam terapi periodontitis untuk menghilangkan jaringan inflamasi, kalkulus, dan koloni bakteri. Studi ini bertujuan untuk membahas tentang penatalaksanaan perawatan kuretase gingiva pada seorang pasien perempuan berusia 26 tahun yang mengalami gingivitis dengan poket periodontal sedalam $4 \mathrm{~mm}$ pada gigi premolar sebelah kiri rahang atas, yang kemudian dilakukan perawatan scalling dan kuretase gingiva. Hasil pemeriksaan klinis perawatan mendapatkan gingiva sudah tampak normal, tidak ada pembengkakan seperti kondisi sebelum kuretase dan kedalaman poket telah berkurang sekitar $2 \mathrm{~mm}$.
\end{abstract}

Kata kunci: penyakit periodontal, poket periodontal, kuretase gingiva

\section{PENDAHULUAN}

Periodontitis merupakan faktor risiko yang berperan terhadap gangguan fungsi pengunyahan dan hilangnya gigi. Kelainan ini masih sering dijumpai dalam masyarakat. Secara umum penyakit periodontal disebabkan oleh plak bakteri pada permukaan gigi. Plak merupakan lapisan tipis biofilm yang berisi kumpulan mikroorganisme patogen. ${ }^{1}$ Penyakit periodontal diawali ketika plak atau kalkulus terakumulasi pada permukaan gigi. Kalkulus sendiri mempunyai kontribusi sebagai faktor etiologi penyakit periodontal. Kalkulus adalah plak gigi yang terklasifikasi, tidak mengandung mikroorganisme hidup seperti plak gigi. Meskipun demikian, permukaan yang berpori memungkinkan terakumulasinya plak. Pembentukan plak atau biofilm tersebut dapat dicegah dengan cara mekanis 
dengan menggosok gigi dan membersihkan interdental gigi. $^{2}$

Perawatan periodontal merupakan tindakan yang dilakukan untuk menghilangkan penyakit yang ada dan mencegah kembalinya penyakit tersebut, dengan cara perawatan yang sesuai. Tindakan scaling, root planing, kuretase dan menjaga kebersihan rongga mulut yang baik, akan memperbaiki keadaan peradangan dan poket, bahkan pada pasien tertentu dapat menghilangkan seluruh penyakit yang ada. ${ }^{2}$

Scaling dan root planning merupakan perawatan inisial yang dilakukan secara berurutan dengan tujuan terjadi perubahan dalam mikrobiota yang disertai dengan berkurangnya atau hilangnya peradangan klinis. Apabila setelah dilakukan perawatan inisial masih ditemukan adanya inflamasi, edema, dan poket dengan kedalaman 3-5 $\mathrm{mm}$ pada gingiva, maka dapat dilakukan perawatan lanjutan yaitu kuretase. ${ }^{3}$

Kuretase adalah prosedur untuk menyingkirkan jaringan granulasi terinflamasi yang berada pada dinding poket periodontal. Kuretase diperlukan terutama bila diharapkan terjadinya perlekatan gingiva baru pada poket dengan cara membersihkan jaringan yang rusak, sementum nekrotik, serta jaringan yang dapat mengiritasi gingiva yang merupakan dinding dari poket. ${ }^{4}$

Perawatan scaling dan root planning dengan kuretase terbukti dapat meningkatkan perkembangan perbaikan kondisi jaringan periodontal. ${ }^{4}$ Mengingat masih seringnya dijumpai pasien dengan periodontitis maka kami mengemukakan suatu kasus periodontitis marginalis kronis disertai poket periodontal dengan perawatan scaling dan kuretase.

\section{LAPORAN KASUS}

Seorang pasien perempuan berusia 26 tahun berdomisili di Malalayang, datang ke klinik RSGM PSPDG UNSRAT, dengan keluhan adanya rasa tebal dan kasar pada giginya, gusi bengkak dan berdarah saat menyikat gigi. Pasien merasakan keadaan ini sekitar 2 tahun yang lalu. Pasien tidak memiliki riwayat penyakit sistemik tetapi memiliki alergi terhadap makanan seafood.
Pada pemeriksaan ekstraoral tidak ditemukan kelainan atau abnormalitas. Pada pemeriksaan intraoral ditemukan adanya daerah kemerahan dan inflamasi pada regio kiri atas belakang. Dari hasil pemeriksaan oral hygiene ditemukan skor 2,4 atau O-HIS sedang. Dari pemeriksaan poket periodontal terdapat poket pada bagian mesial dan palatal gigi 24 dan 25 sedalam $4 \mathrm{~mm}$. Diagnosa dari kasus ini ialah periodontitis marginalis kronis, dan rencana perawatan yang dilakukan ialah menghilangkan faktor etiologi yaitu scaling dan kuretase. Pemeriksaan penunjang yang dilakukan pada pasien ialah pemeriksaan foto rontgen. Pasien dirujuk untuk melakukan rontgen foto panoramik di Laboratorium Klinik Kanaka. Gambar 1 memperlihatkan hasil foto rontgen panoramik yaitu adanya kehilangan tulang secara horisontal hampir di seluruh regio gigi.

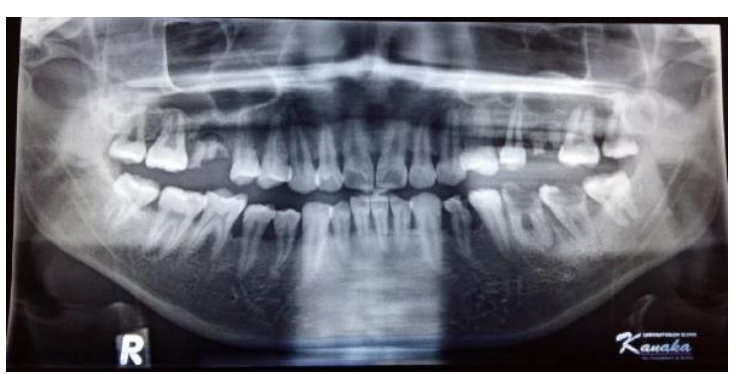

Gambar 1. Foto rontgen panoramik

Gambar 2 memperlihatkan gambaran klinis satu minggu setelah dilakukan perawatan inisial. Perawatan dilakukan dengan persetujuan pasien. Langkah pertama yaitu pasien diberikan informed consent untuk menjelaskan tujuan dilakukan perawatan, yaitu membersihkan karang gigi yang terdapat pada seluruh permukaan gigi pasien. Tindakan scaling dapat menyebabkan gigi terasa linu dan terjadi sedikit pendarahan pada rongga mulut karena proses pengambilan kalkulus pada supragingival dan subgingival. Edukasi ke pasien bila kalkulus tidak dibersihkan maka dapat menimbulkan penyakit yang lebih parah dan menyebabkan bau mulut. Langkah kedua, dilakukan scaling menggunakan ultrasonic scaler, dilanjutkan dengan polishing permukaan gigi dengan campuran pasta dan 
pumice menggunakan brush dan pemberian Dental Health Education (DHE) kepada pasien.

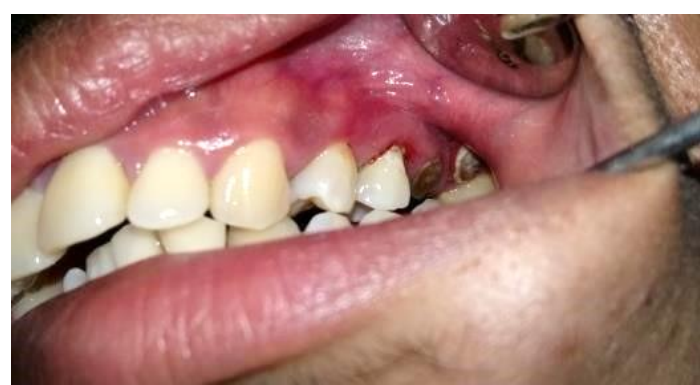

Gambar 2. Gambaran klinis satu minggu setelah dilakukan perawatan inisial. Inflamasi masih tampak di bagian bukal gigi 24 dan 25 .

Pada kunjungan berikut dilakukan evaluasi pasca perawatan scaling. Pada pemeriksaan subjektif pasien masih mengeluhkan sedikit linu. Pada pemeriksaan objektif masih ditemukan adanya poket pada gigi 24 dan 25 dengan kedalaman $4 \mathrm{~mm}$. Dari hasil evaluasi tersebut dapat disimpulkan bahwa kondisi gingiva pasien merupakan indikasi perawatan kuretase sehingga disarankan kepada pasien untuk melakukan perawatan tersebut dan pasien menyetujuinya.

Gambar 3 memperlihatkan gambaran klinis saat dilakukan perawatan kuretase. Pada perawatan ini digunakan metode kuretase manual menggunakan kuret Gracey no. 11-12 dan 13-14. Kuret dimasukkan ke dalam sulkus gingiva searah aksis gigi sampai dasar poket, dan bagian yang tajam dari kuret Gracey diletakkan pada daerah epitel sulkuler, kemudian lakukan pengerokan beberapa kali sampai jaringan granulasi terangkat semua dan tidak terdapat jaringan granulasi lagi. Setelah itu daerah operasi diirigasi dengan larutan $\mathrm{NaCl}$ fisiologis 0,9\% kemudian akuades sampai bersih. Pembersihan dan pengeringan daerah operasi dengan menggunakan tampon steril. Kemudian gingiva diadaptasikan ke permukaan gigi dengan cara menekan gusi ke arah gigi dengan jari selama 1-3 menit.

Gambar 4 memperlihatkan pemasangan periodontal pek dengan mencampur pasta basis dan pasta akselerator sama panjang, yang diaduk sampai didapatkan warna yang merata. Dalam 2-3 menit pasta yang telah diaduk sudah dapat dibentuk dan ditempatkan di atas luka. Untuk menempatkan periodontal pek, lebih dulu dibentuk menjadi batangan sepanjang luka bedah yang hendak dibalut. Agar periodontal pek tidak melekat ke tangan, jari tangan sebaiknya diolesi vaselin. Dengan lebih dahulu mengeringkan daerah luka bedah, batangan periodontal pek ditempatkan pada daerah luka bedah dan ditekan sepanjang gingival dan interproksimal. Pada permukaan vestibular penekanan dapat dilakukan dengan menekan bibir atau pipi pasien sehingga pembalut tidak melekat ke jari. Periodontal pek harus membungkus sebagian gigi dan gingiva. Perlu diperhatikan periodontal pek pada daerah gigi tidak sampai menghalangi oklusi agar tidak mudah lepas karena pecah dan tidak meluas terlalu jauh ke arah lipatan mukosa bukal sehingga tidak mengiritasi bila telah keras.

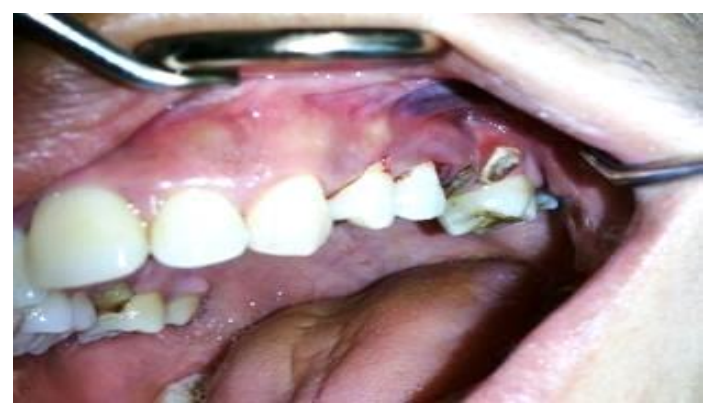

Gambar 3. Gambaran klinis saat dilakukan perawatan kuretase. Terlihat adanya pembengkakan di gigi 24 dan 25 .

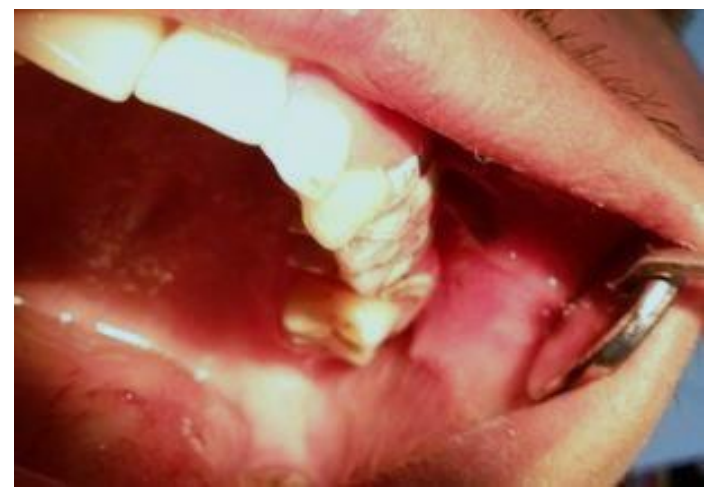

Gambar 4. Gambaran klinis pemasangan periodontal pek

Pasien diberikan instruksi pasca kuretase berupa menghindari makan makanan yang dapat merangsang perdarahan seperti 
makanan panas, dan dianjurkan untuk tidak makan kurang lebih 1 jam setelah prosedur kuretase, tidak berkumur terlalu keras, menjaga kebersihan gigi dan mulut dengan menyikat gigi secara teratur kecuali daerah pasca-kuretase. Pada daerah pasca-kuretase tidak boleh dimainkan dengan lidah, tangan, atau digunakan untuk mengunyah, serta menggunakan obat kumur mengandung antiseptik 2x sehari untuk mengontrol plak. Pasien dianjurkan agar tidak merokok dan mengonsumsi alkohol selama proses penyembuhan, diberikan antibiotik amoksisilin $500 \mathrm{mg} 3 \times 1$, anti inflamasi asam mefenamat $500 \mathrm{mg} 3 \times 1$, betadine gargle 2 dd gargle, dan vitamin B kompleks 1 tablet sehari agar mempercepat penyembuhan.

Gambar 5 A dan B memperlihatkan gambaran klinis dua minggu setelah dilakukan perawatan kuretase. Pada pemeriksaan subjektif, pasien sudah tidak ada keluhan, namun terdapat kalkulus pada regio 2 dan 3 pada bagian bukal dan lingual sehingga perlu dilakukan scaling kembali. Pada pemeriksaan objektif tampak bahwa periodontal pek sudah terlepas, namun sudah tidak ada pendarahan atau luka yang tersisa sehingga tidak dilakukan pemasangan pek lagi. Pada tahap kontrol ini pasien juga diberikan instruksi untuk tetap menjaga kebersihan gigi dan mulut.

Gambar 6 A dan B memperlihatkan gambaran klinis tiga minggu setelah dilakukan perawatan kuretase. Pada tahap kontrol ini dilakukan pemeriksaan subjektif dan didapatkan bahwa tidak ada keluhan lagi serta gusi sudah tidak berdarah saat menyikat gigi. Pada pemeriksaan objektif berupa pemeriksaan poket didapatkan bahwa pada gigi 24 (PD;2 mm) dan gigi 25 (PD; $2 \mathrm{~mm}$ ). Di samping itu, gingiva pasien sudah tampak normal, tidak ada yang bengkak seperti kondisi sebelum kuretase. Pasien juga diberikan instruksi untuk tetap menjaga kebersihan gigi dan mulut.
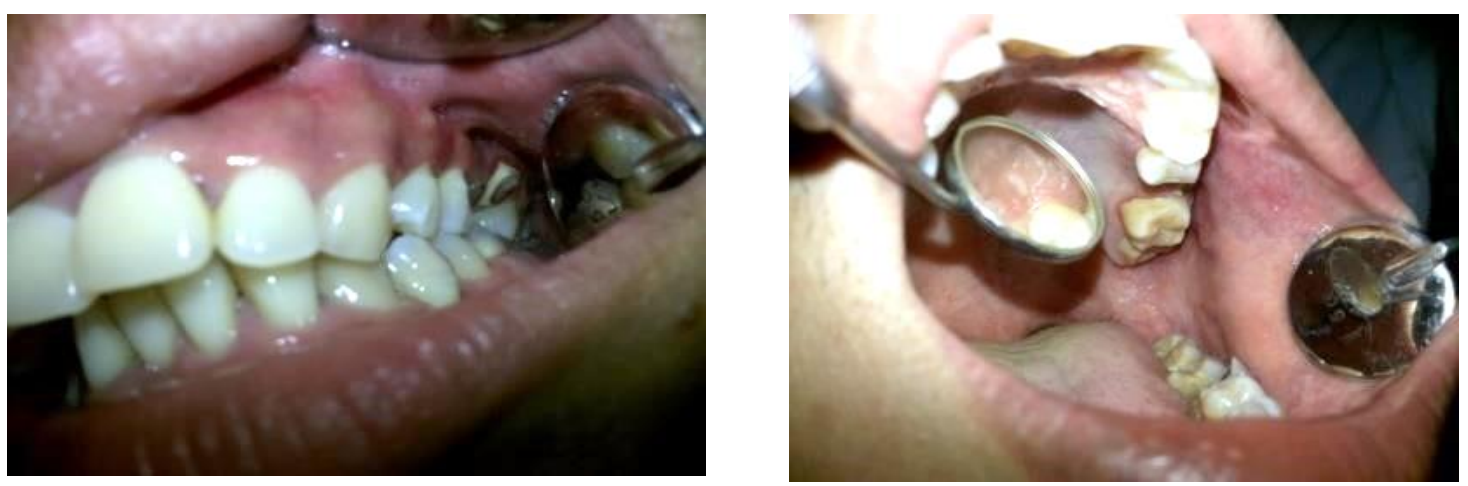

Gambar 5. Keadaan gigi pada saat kontrol pertama. Terlihat gigi dalam keadaan baik dan tidak terdapat inflamasi pada gigi 24 dan 25.
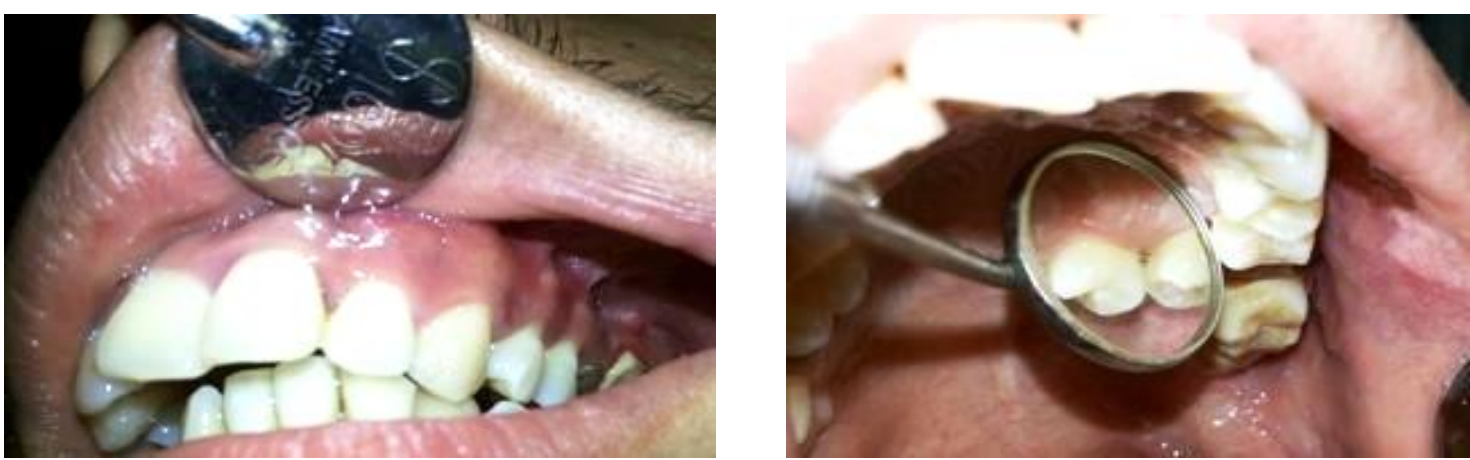

Gambar 6.. Keadaan gigi saat kontrol kedua. Gigi tampak dalam keadaan baik dan tidak terdapat inflamasi pada gigi 24 dan 25 . 


\section{BAHASAN}

Periodontitis merupakan infeksi pada jaringan penyangga gigi yang disebabkan oleh bakteri yang berada di dalam biofilm baik pada batas gingiva ataupun di bagian bawahnya. Periodontitis juga menyebabkan kerusakan tulang alveolar dan ligamen periodontal sehingga membentuk poket, menyebabkan resesi atau keduanya., Penyakit periodontal sendiri memiliki etiologi dan patogenesis yang multifaktorial; adanya bakteri patogen yang berperan tidak cukup menyebabkan terjadinya kelainan. ${ }^{7}$

Bakteri plak merupakan penyebab primer dari penyakit periodontal. Hasil dari produk bakteri dapat mengubah metabolisme dan menghambat pertumbuhan jaringan sel inang. Sistem imun melibatkan interaksi yang kompleks antara molekul regulasi dan sel. Kerusakan jaringan diakibatkan oleh produk-produk dari bakteri. ${ }^{2,5}$

Pada pasien ini diberikan pengobatan dengan antibiotik sistemik amoksisilin 500 mg 3x1 dan antiseptik berupa Betadine ${ }^{\circledR}$ gargle selama 4 hari. Saat evaluasi 2 minggu setelah kuretase telah didapatkan perbaikan yang nyata. Penggunaan antibiotik pada kasus periodontitis baik yang kronis maupun bentuk agresif bertujuan untuk mengeliminasi faktor penyebab yaitu bakteri patogen. ${ }^{8}$ Terdapat 8 kelompok antibiotik yang telah dipergunakan dan dievaluasi pada pengobatan periodontitis yaitu tetrasiklin, minosiklin, doksisiklin, eritromisin, klindamisin, ampisilin, amoksisilin dan metronidazol. ${ }^{9}$ Pemberian amoksisilin masih bermanfaat pada penanganan pasien dengan periodontitis agresif baik secara sistemik maupun pemberian lokal. Dosis yang direkomendasi ialah $3 \times 500 \mathrm{mg}$ selama 8 hari. Bhat et $\mathrm{al}^{6}$ meneliti 40 pasien dengan periodontitis kronis yang dilakukan scaling and root planning (SRP), dibagi atas 2 kelompok, yaitu kelompok dengan pemberian metronidazol + amoksisilin, dan kelompok dengan pemberian siprofloksasin. Bhat et al mendapatkan penurunan periodontal index yang lebih baik pada kelompok yang diberikan metronidazol + amoksisilin. ${ }^{6}$

Perawatan kuretase bertujuan untuk mengurangi dan menghilangkan terjadinya poket periodontal serta memperbaiki dan merangsang terbentuknya perlekatan baru, memperbaiki gingiva menjadi sehat baik warna, kontur, konsistensi dan tekstur permukaan. ${ }^{10}$ Prosedur perawatan kuretase dilakukan menggunakan kuret Gracey untuk gigi posterior. Bagian yang tajam dari kuret Gracey di arahkan pada daerah epitel sulkuler kemudian dilakukan pengerokan sepanjang jaringan lunak sehingga jaringan granulasi seperti fibroblastik dan proliferasi angioblastik, serta kalkulus yang berisi akumulasi bakteri dapat terangkat. ${ }^{11}$

Setelah dilakukan perawatan kuretase akan terjadi proses perbaikan pada epitel sulkuler yang berlangsung antara 2-7 hari, sedangkan untuk perbaikan epitel cekat terjadi selama 5 hari, pengerutan margin gingiva terjadi selama 1 minggu dan penyembuhan sempurna terjadi antara 2-3 minggu setelah kuretase. Penyembuhan tersebut dipengaruhi oleh beberapa faktor seperti faktor sistemik, sistem kekebalan tubuh pasien, dan kepedulian pasien untuk menjaga kebersihan rongga mulutnya. ${ }^{12}$ Pada pasien ini saat kontrol dua miggu setelah perawatan kuretase, pemeriksaan objektif tampak tidak terdapat pendarahan atau luka yang tersisa maupun inflamasi pada gigi 24 dan 25 . Tiga minggu setelah dilakukan perawatan kuretase, pada pemeriksaan subjektif tidak ada keluhan lagi serta gusi sudah tidak berdarah saat menyikat gigi. Pemeriksaan objektif berupa pemeriksaan poket mendapatkan pada gigi 24 (PD;2 $\mathrm{mm}$ ) dan gigi 25 (PD; $2 \mathrm{~mm}$ ), di samping itu, gingiva pasien sudah tampak normal, tidak ada yang bengkak seperti kondisi sebelum kuretase.

\section{SIMPULAN}

Telah dilaporkan seorang pasien dengan periodontitis yang disertai poket periodontal sedalam $4 \mathrm{~mm}$. Pada pasien ini telah dilakukan perawatan inisial, scaling, polishing, perawatan kuretase dengan pemasangan pek, dan DHE yang telah sesuai dengan standar perawatan periodontitis yang disertai poket. Saat evaluasi 2 minggu setelah kuretase telah didapatkan perbaikan yang nyata. 


\section{Konflik Kepentingan}

Penulis menyatakan tidak terdapat konflik kepentingan dalam studi ini.

\section{DAFTAR PUSTAKA}

1. Tantin E. Periodontitis dan diabetes melitus. Stomatognatic. 2012;9(3):152-4.

2. Carranza FA, Takei HH. 2012, Rationale for periodontal treatment. In: Newman MG, Takei HH, Klokkevold PR, Carranza FA. Carranza's Clinical Periodontology (11th ed). Elsevier Inc., W.B. Saunders Co, 2012; p. 387-91.

3. Mittal A, Nichani AS, Venugoval R, Rajani V. The effect of various ultrasonic and hand instrumens on the root surfaces of human single rooted teeth: a planimetric and profilometric study. J Indian Soc Perodontol. 2014;18(6): 710-7.

4. Prahasanti C. Kehilangan perlekatan jaringan pada penderita periodontitis setelah dirawat kuretase. Maj Ked Gigi (Dent J). 2001;34(3a): 199-201.

5. Carranza FA. Clinical Periodontology (9th ed). Philadelphia: WB Saunders, 2006; p. 160-83, 349-50.

6. Bhat Muzafar A, Amin SS, Bhat Mudasir A, Huda. Effects of amoxicillin - metroni- dazole combination versus ciprofloxacin as an adjunct to nonsurgical periodontal therapy of chronic generalized periodontitis. International Journal of Contemporary Medical research. 2018;5(9):116-9.

7. Kuswandani SO, Masulili SLC, Soedarsono N, Kemal Y. Academic stress influences periodontal health condition and interleukin-1 beta level. Journal of Dentistry Indonesia. 2015;21(1):16-20.

8. Prakasam A, Elavarasu SS, Natarajan RK. Antibiotics in the management of aggressive periodontitis. J Pharm Bioallied Sci. 2012;4(Suppl 2):S252-S255.

9. Kapoor A, Malhotra R, Grover V, Grover D. Systemic antibiotic therapy in periodontics. Dent Res J (Isfahan). 2012; 9(5):505-15.

10. Witjaksono W, Roselinda A, Kannan TP. Clinical evaluation in periodontitis patient after currettage. Dent J (Majalah Kedokteran Gigi), 2006; 39(3):102-6.

11. Kornman KS. Mapping the pathogenesis of periodontitis: a new look. J Periodontol. 2018;79(8):1560-8.

12. Dinyati M, Andi MA. Kuretase gingiva sebagai perawatan poket periodontal. Makassar Dent J. 2016;5(2):58-64. 